\title{
PELATIHAN PASAR TANGGUH KEPADA RELAWAN UNTUK PENCEGAHAN PENYEBARAN COVID 19 DI SURABAYA RAYA
}

\author{
Andy Usmina Wijaya, Wahyu Kurniawan, Sekaring Ayumeida Kusnadi \\ Fakultas Hukum Universitas Wijaya Putra
}

usmina7@gmail.com

\begin{abstract}
Abstrak
Pandemi Covid 19 sampai saat ini masih berlangsung di Indonesia. Pemerintah telah melakukan berbagai upaya pencegahan penyebaran mata rantai Covid 19 secara terukur, terkoordinasi dan intensif. Salah satu bentuk upaya yang dilakukan adalah menjadikan program pasar tangguh Covid 19. Kegiatan pelatihan pasar tangguh kepada relawan ini merupakan bentuk implementasi dari program pemeritah melalui Badan Nasional Penanggulangan Bencana (BNPB) dalam memutus rantai penyebaran Covid 19 di Surabaya Raya. Tujuan kegiatan dari pelatihan pasar tangguh ini adalah membekali para relawan dalam melaksanakan edukasi dan sosialisasi kepada pengelola, pedagang dan pengunjung pasar terkait upaya-upaya untuk melindungi diri dari virus Covid 19 serta memutus rantai penyebaran virus Covid 19 selama berada di pasar. Mekanisme pelaksanaan kegiatan ini adalah memberikan pelatihan kepada para relawan pasar tangguh di Surabaya Raya yang meliputi (1) pemahaman tentang konsep tentang pasar tangguh; (2) edukasi mengenai protokol kesehatan tentang Covid 19; dan (3) peningkatan kemampuan dalam komunikasi publik. Hasil yang diharapkan adalah para relawan pasar tangguh dapat memahami konsep tentang pasar tangguh serta mampu melaksanakan hasil pelatihan pada pasar pasar yang ada di Surabaya Raya, sehingga dapat memutus rantai penyebaran Covid 19.
\end{abstract}

Kata Kunci : pasar tangguh, protokol kesehatan, pencegahan Covid 19

\section{PENDAHULUAN}

Sampai saat ini kasus mengenai penyebaran Corona Virus Disease 2019 atau yang biasa dikenal dengan nama Covid 19 yang berasal dari kota Wuhan Cina masih menjadi topik utama di seluruh dunia, tidak terkecuali di negara Indonesia. Bukan hanya mengenai penyebaran dan penularannya saja yang cepat, namun juga masih belum ditemukan vaksin dan obat yang pasti guna menyembuhkan penyakit Covid 19. World Health Organization (WHO) atau organisasi kesehatan dunia menetapkan kasus penyebaran Covid 19 sebagai pandemi. Hal ini berarti suatu keadaan peningkatan jumlah kasus dari penyakit secara tiba-tiba telah menyebar di beberapa negara serta menjangkiti banyak orang.
Penyakit Covid 19 yang memiliki gejala umum seperti demam tinggi, batuk kering, sakit tenggorokan, kelelahan, sesak napas dan penurunan fungsi tubuh dalam 14 hari, merupakan ancaman seluruh masyarakat di dunia termasuk Indonesia.

WHO dalam menangani pandemi Covid 19 mengeluarkan beberapa kebijakan dan protokoler untuk mencegah penyebaran dan penularan di dunia diantaranya adalah penerapan social ditancing, physical distansing, stay at home,dan cuci tangan. Semua itu merupakan protokol kesehatan bagi setiap orang untuk menekan pandemi Covid 19 ini. Langkah ini dirasa sangat efektif dan memiliki dampak yang signifikan dalam membantu 
mencegah penyebaran dan penularan virus Covid 19 dari orang ke orang.

Berdasarkan arahan dari WHO tersebut serta mengingat meningkatnya kasus Covid 19 di Indonesia, pemerintah mengeluarkan instruksi kepada seluruh kepala daerah di Indonesia memperimbangkan dampak kesehatan dan keselamatan rakyat serta dampak sosial dan ekonomi saat menerapkan kebijakan di daerah masing masing. Mulai dari kegiatan belajar mengajar, pelaksanaan work from home (WFH), memprioritaskan APBN dan APBD dalam kegiatan penekanan penyebaran pandemi Covid 19, sampai perlunya pelaksanaan Pembatasan Sosial Berskala Besar (PSBB).

Pemerintah Daerah pada wilayah Surabaya Raya yang terdiri dari Kota Surabaya, Kabupaten Sidoarjo dan Kabupaten Gresik juga mengikuti instruksi Pemerintah Pusat untuk melakukan kebijakan guna mencegah penyebaran dan penularan virus Covid 19 ini. Berbagai upaya yang telah dilakukan oleh Pemerintah daerah di Surabaya Raya untuk mencegah penyebaran virus ini adalah memberikan arahan kepada masyarakat agar menjaga kesehatan, melaksanakan olahraga yang teratur, makan makanan yang bergizi, serta istirahat yang cukup agar imunitas tetap terjaga. Selain itu, pemerintah daerah di wilayah Surabaya Raya juga membagikan hand sanitaizer secara gratis pada berbagai fasilitas publik, mengecek suhu tubuh warga masyarakat yang beraktifitas di luar, membangun wastafel di berbagai pusat keramaian, membuat himbauan untuk melaksanakan protokol kesehatan berbentuk poster, baliho dan lainnya.

Mengingat peningkatan jumlah warga masyarakat yang positif terkonfirmasi virus Covid 19 di wilayah Surabaya Raya yang tajam akhirnya Pemerintah Daerah masing masing memutuskan untuk menetapkan PSBB. Kebijakan PSBB tersebut adalah suatu kegiatan yang diterapkan kepada suatu penduduk yang terkena ataupun terkontaminasi sebuah penyakit dengan tujuan untuk mencegah penyebaran virus dari orang kepada orang lain di suatu wilayah. Penerapan PSBB ini dilakukan dengan cara menggurangi aktivitas kegiatan di luar rumah agar dapat memutus rantai penyebaran virus Covid 19. Kebijakan meliburkan sekolah, pondok pesantren dan kampus, menerapkan WFH, stay at home, dan mengurangi kegiatan di tempat umum dan keagamaan adalah contoh PSBB tersebut.
Akan tetapi sampai saat ini di wilayah Surabaya Raya masih saja terjadi peningkatan warga masyarakat yang terkonfirmasi virus Covid 19 walaupun pelaksaanaan kebijakan PSBB telah dilakukan. Munculnya klaster penyebaran virus Covid 19 yang baru terjadi di wilayah Surabaya Raya, salah satunya adalah klaster pasar. Beberapa pasar yang menjadi klaster penyebaran virus Covid 19 adalah pasar Keputran Surabaya dan Pasar Larangan Sidoarjo. Menurut data dari Ikatan Pedagang Pasar Indonesia (IKPPI) menyebutkan bahwa sampai saat ini ada sekitar 653 warga masyarakat yang terkonfirmasi virus Covid 19 dan 32 orang meninggal dunia yang tersebar di 110 pasar tradisional di Indonesia. Kondisi ini dapat memberikan bukti bahwa warga masyarakat Surabaya Raya masih belum sungguh sungguh dalam melaksanakan protokol kesehatan yang dianjurkan oleh Pemerintah untuk menekan penyebaran dan penularan virus Covid 19 ini.

Berangkat dari kondisi diatas tersebut maka para pengabdi masyarakat mengangkat tema mengenai "Pelatihan Pasar Tangguh Kepada Relawan Untuk Pencegahan Penyebaran Covid 19 di Surabaya Raya".

\section{METODE}

Metode pelaksanaan kegiatan pelatihan ini menggunakan pendekatan pemberdayaan masyrakat mengacu pada ekologi perkembangan (ecology of human development) dan lingkungannya yang menyatakan bahwa intervensi sosial harus dapat menyentuh seluruh level relasi antar-individu dan lingkungannya.

Berdasarkan relevansi tersebut diatas, maka program Pelatihan Pasar Tangguh Kepada Relawan Untuk Pencegahan Penyebaran Covid 19 di Surabaya Raya dimulai dengan kegiatan 1) Peningkatan pengetahuan para relawan mengenai arti pentingnya pasar tangguh untuk menekan penyebaran dan penularan Covid 19.2) Peningkatan kemampuan para relawan mengenai public speaking untuk dapat mensosialisasikan dan mengedukasi pasar tangguh. 3) Pengoptimalan organisasi relawan pasar tangguh.

\section{HASIL DAN PEMBAHASAN}

1. Konsep Pasar Tangguh

Pasar pada jaman dahulu bukan hanya berguna sebagai tempat bertemunya antara penjual Lingkungan Hidup dan Bencana

541 
dan pembeli saja, melainkan memiliki fungsi lain yaitu sebagai tempat bertemu antara masyarakat dan bangsawan serta tempat untuk tukar menukar informasi penting yang ada pada jaman dulu. Untuk itu peranan pasar apabila dikelola dengan baik dan benar maka akan berpotensi dalam memajukan dan meningkatkan pertumbuhan ekonomi bagi rakyat sebagai lapangan pekerjaan untuk masyarakat ekonomi lemah, menengah dan atas.

Pasar adalah tempat yang strategis untuk mengembangkan budaya khususnya budaya interaksi dan komunikasi serta menjaga nilai kearifan lokal yang hidup melalui sarana pasar tersebut. Pada pasal 28 huruf I ayat (3) UndangUndang Dasar Republik Indonesia Tahun 1945 menyatakan bahwa identitas budaya dan hak masyarakat tradisional dihormati selaras dengan perkembangan zaman dan peradaban. Pasar sebagai salah satu warisan budaya bangsa Indonesia wajib untuk dijaga dan dipertahankan sebagai wujud dari identitas budaya serta salah satu kebudayaan nasional Indonesia. Hal tersebut diatur dalam pasal 32 ayat (1) UUD RI 1945 yang menyatakan bahwa "Negara memajukan kebudayaan nasional Indonesia di tengah peradaban dunia dengan menjamin kebebasan masyarakat dalam memelihara dan mengembangkan nilai-nilai budayanya".

Akan tetapi berkaitan dengan pandemi virus Covid 19 yang melanda seluruh dunia termasuk wilayah Surabaya Raya, pasar menjadi tempat yang mengkhawatirkan dalam penyebaran dan penularan virus Covid 19 ini. Hal tersebut akan terjadi apabila semua orang yang berada di pasar termasuk penjual, pembeli, pengelola pasar dan lainnya tidak taat dalam melaksanakan protokol kesehatan yang dihimbau oleh pemerintah daerah masing-masing.

Pasar tangguh merupakan tempat jual beli barang dengan jumlah penjual lebih dari satu yang memilikisistem ketahanan bencana atau yang dikemal sebagai kapasitas untuk pertama, mengantisipasi, meminimalisasi dan menyerap potensi stres atau kekuatan destrukti melalui adapatasi atau resistensi. Kedua, mengelola atau menjaga fungsi dan struktur dasar tertentu selama peristiwa bencana berlangsung. Ketiga, memulihkan atau melambungkan balik keadaan setelah terjadi suatu peristiwa bencana. Fokus dari pasar tangguh adalah memberikan penekanan yang lebih berat kepada hal-hal yang dapat dilakukan masyarakat pasar untuk diri sendiri serta cara memperkuat kapasitas mereka dari pada berkonsentrasi terhadap kerentanan mereka pada bencana atau kejutan dan tekanan lingkungan atau kebutuhan dalam kedaruratan. Tidak ada pasar yang dapat benarbenar bebas dari bahaya alamiah ataupun bahaya akibat ulah manusia seperti pandemi virus Covid 19 saat ini.

Konsep pasar tangguh dalam menghadapi pandemi virus Covid 19 ini adalah: 1) Ada satgas atau tim khusus yang menangani penekanan penyebaran virus Covid 19 ini. 2) Penerapan protol kesehatan di pasar yang bersangkutan. 3) Pelaksanaan sirkulasi pengunjung dengan menggunakan sistem one gate way, dimana antara pintu masuk dan pintu keluar tidak menjadi satu seperti biasanya. 4) Pemberlakuan jam operasional pada aktifitas kegiatan di pasar yang bersangkutan oleh penjual, pembeli maupun pengelola pasar. 5) Pembatasan jumlah pengunjung dari pasar yang bersangkutan baik itu oleh penjual, pembeli maupun pengelola pasar. 6) Pemakaian faceshield dan masker sebagai alat pelindung diri (APD) oleh penjual, pembeli, pengelola pasar serta para pengunjung pasar lainnya. 7) Tidak adanya kontak secara langsung oleh penjual maupun pembeli terkait dengan alat pembayaran (uang).

\section{Pelatihan Pasar Tangguh}

Tujuan dari pelatihan pasar tangguh ini adalah mewujudkan suatu pasar yang tangguh dalam mengantisipasi, mengelola dan memulihkan pandemi virus Covid 19. Agar mereka yang berada di pasar tersebut baik penjual, pembeli, pengelola pasar maupun pengunjung pasar lainnya dapat melakukan hal tersebut maka perlu adanya sosialisasi dan edukasi kepada mereka terkait upaya-upaya untuk melindungi diri sendiri dan orang lain dari penyebaran dan penularan virus Covid 19 ini.

Dalam pelatihan ini dijelaskan mengenai pelaksanaan pasar tangguh diantaranya mekanisme pasar tangguh yang meliputi 1) menempatkan relawan yang berdomisili di sekitar pasar, 2) para relawan tersebut bertugas selama 14 hari. 3) sebelum ditugaskan, para relawan tersebut mendapat pembekalan dan pelatihan mengenai pelaksanan pasar tangguh. 4) para relawan tersebut bertugas memberikan edukasi dan sosialisasi Lingkungan Hidup dan Bencana

542 
mengenai protokol kesehatan Covid 19 ini. 5) agar para relawan mendapatkan legalitas dalam pelaksanaan tugas maka dibekali dengan Surat Tugas, Alat Perlidungan Diri (APD) dan tanda pengenal dari instansi yang terkait seperti BPBD masing-masing kabupaten/kota.

Berikutnya pelatihan pasar tangguh ini juga menjelaskan panduan pencegahan Covid 19 bagi para pedagang sebagai subyek pelaksanaan pasar tangguh. Ada 6 (enam) kunci pencegahan dari penyebaran virus Covid 19 yaitu 1) kalau para pedagang sakit, diharapkan tetap istirahat di rumah dan jangan bekerja di pasar. Karena ditakutkan akan membawa virus Covid 19 bagi orang lain. 2) para pedagang diharapkan menggunakan masker setiap berhubungan dengan pelanggan/pembeli seperti jual beli menggunakan masker. 3) melaksanakan protokol kesehatan berupa cuci tangan dengan sabun dan hand sanitizer secara berkala. 4) para pedagang diharapkan pula membersihkan lapak jualan \& permukaan yang sering disentuh dengan disinfektan secara terbuka. 5) membuat pembatas dengan jarak yang cukup memadai antara penjual dan pembeli. Selanjutnya pelatihan relawan pasar tangguh memberikan prosedur penjualan berdagang di pasar meliputi 3 (tiga) hal yaitu sebelum bekerja, saat bekerja dan setelah bekerja.

\section{Pelatihan Komunikasi Publik}

Agar tujuan dari pemerintah dalam rangka memutus mata rantai penyebaran virus Covid 19 ini menunjukkan hasil maka perlu ada komunikasi yang baik kepada masyarakat yang ada berada di pasar yang bersangkutan. Setiap orang pasti pernah melakukan kegiatan komunikasi. Komunikasi merupakan satu aktivitas yang harus dilakukan karena pada dasarnya manusia adalah individu dan makhluk sosial yang selalu ingin bersosialisasi atau berhubungan dengan orang lain. Sebagai makhluk individu, manusia ingin terlihat menonjol, sedangkan sebagai makhluk sosial manusia tidak dapat hidup sendiri, selalu bergantung dan ingin diperhatikan atau diperhitungkan dalam kelompok. Maka manusia selalu membutuhkan orang lain dalam kehidupannya. Proses interaksi manusia dengan manusia lainnya inilah yang memerlukan kegiatan komunikasi. komunikasi adalah penyampaian informasi dan pengertian dari seseorang kepada orang lain. komunikasi akan dapat berhasil apabila sekiranya timbul saling pengertian, yaitu jika kedua belah pihak, si pengirim dan si penerima informasi dapat memahaminya. Hal ini tidak berarti bahwa kedua belah pihak harus menyetujui sesuatu gagasan tersebut, tetapi yang penting adalah kedua belah pihak sama-sama memahami gagasan tersebut. Dalam keadaan seperti inilah baru dapat dikatakan komunikasi telah berhasil baik (komunikatif).

Berdasarkan konsep komunikasi publik, fungsi dari komunikasi penting dipahami bahwa kegiatan utama komunikasi publik adalah melakukan komunikasi. Komunikasi dalam konteks ini menyangkut paling tidak empat langkah khusus berikut, pertama keterampilan, yaitu berkaitan dengan keterampilan komunikasi yang harus dimiliki oleh para relawan. Di sini, seorang relawan menjadi technician of communication yang memiliki ketrampilan dasar untuk menulis, melakukan riset, merumuskan rencana, dan mengevaluasi hasil. Kedua, yakni berkaitan dengan tugas-tugas yang harus dijalankan oleh seorang relawan. Tugas-tugas terkait dengan komunikasi publik misalnya berkaitan dengan pembuatan release, pemantauan media massa, pembuatan newsletter, fotografi, penyelenggaraan special event, bahkan saat ini sudah mulai mengelola website organisasi. Jadi, tugas para relawan adalah tugas yang terkait dengan kegiatan komunikasi publik yang dijalankan organisasi. Ktiga, sistem. Hubungan masyarakat tidak hanya berkaitan dengan keterampilan dan tugas, tetapi juga yang berkaitan dengan penciptaan sistem komunikasi. Jadi, sebuah usaha yang sistematis untuk mengumpulkan informasi, membina hubungan dengan berbagai pihak, serta menciptakan berbagai kelompok komunitas dan konsumen yang dapat dipakai sebagai cara untuk memperoleh masukan dan pandangan publik. Keempat, sistem operasi. Komunikasi Publik berkaitan dengan usaha untuk membangun sistem komunikasi dua arah antara organisasi dan berbagai publik sehingga organisasi dapat menyampaikan dengan segera berbagai pesan dan informasi untuk berbagai publik. Sebaliknya, publik juga dengan cepat menyampaikan pesan mereka kepada organisasi. Dengan kata lain, pemerintah daerah melalui para relawan ini akan dengan cepat mengetahui keinginan, aspirasi, dan gagasan publik tentang hal yang dilaksanakan pemerintah.

Lingkungan Hidup dan Bencana 543 
Komunikasi akan dapat berjalan dengan efektif apabila ada beberapa aturan dan kaidah yang diikuti, yaitu: pertama, komunikator menghargai setiap individu, orang maupun kelompok yang dijadikan sasaran komunikasi. Hal ini mensyaratkan bahwa seseorang yang melakukan komunikasi bisa menempatkan diri, tidak menganggap dirinya sebagai orang yang paling tahu dan paling benar. Kedua, komunikator harus mampu menempatkan diri pada situasi atau kondisi yang dihadapi orang lain. Setiap orang yang melakukan komunikasi harus mampu mendengar dan dan siap menerima masukan apapun dengan sikap yang positif. Hal ini akan sangat sulit dilakukan manakala orang tersebut tidak dapat dikritik atau tidak siap menerima kritik. Menerima kritik memang tidak mudah. Tetapi kemampuan untuk menerima apapun masukan dengan sikap baik akan membawa pengaruh positif pada orang tersebut. Ketiga, pesan diterima oleh penerima pesan dan dapat didengarkan dengan baik. Hal ini berkaitan dengan media yang digunakan. Seringkali orang melakukan komunikasi dengan individu maupun kelompok, tetapi pesan tidak dapat dipahami karena media atau alat yang digunakan tidak mendukung. Misalnya, suara di telepon putusputus, atau microphon yang mendengung, atau suara di telepon yang terlalu lemah. Beberapa hal tersebut mengakibatkan penerima pesan kesulitan memahami isi pesan. Akibatnya selain tidak respon, pemberi pesan justru tidak akan didengarkan atau diperhatikan. Keempat, kejelasan pesan sehingga tidak menimbulkan multi interpretasi. Hampir mirip efeknya dengan permasalahan media yang rusak, maka bagian ini berkaitan dengan kejelasan isi pesan itu sendiri. Misalnya apabila pemberi pesan menggunakan istilah-istilah yang sulit dipahami oleh penerima pesan, maka jelas akan sulit bagi penerima pesan untuk memahami isi pesan dan akhirnya umpan balik juga tidak akan muncul. Demikian juga bila pemberi pesan tidak jelas dalam menyampaikan pesan akibat penggunaan bahasa yang tidak sesuai dengan latar belakang penerima pesan, maka akan muncul berbagai interpretasi. Akhirnya isi pesan akan bergeser, dan komunikasi tidak dapat mencapai tujuannya. Kelima, berkaitan dengan sikap rendah hati dan mau mendengarkan orang lain Hal ini berkaitan dengan karakter dan sikap individu masing-masing, baik pemberi maupun penerima pesan. Termasuk di dalam sikap dan sifat ini adalah kerelaan untuk rendah hati, menghargai, dan mau mendengarkan orang lain.

\section{Mengoptimalkan organisasi relawan}

Sering kita melihat, tujuan mulia yang ingin dicapai suatu organisasi berakhir sebatas slogan. Padahal, jika tujuan tersebut dapat didalami, dipahami, dan dilaksanakan dengan baik, bisa menjadi kekuatan yang dahsyat agar organisasi terus tumbuh dan berkembang. Dari sisi organisasi, tujuan yang bermakna dapat diartikan sebagai aspirasi untuk membuat kehidupan yang lebih baik bagi para pemangku kepentingan (stakeholders) pada masa sekarang dan mendatang. Namun, kenyataannya, ada kesenjangan antara harapan dan kenyataan. Banyak pimpinan perusahaan mengaku memiliki tujuan yang bermakna dan tindakan yang baik bagi masyarakat, tetapi tidak demikian dalam praktiknya.

Organisasi yang baik bisa di katakan organisasi yang terorganisir, organisasi yang mempunyai visi dan misi atau tujuan yang jelas , organisasi yang mempunyai perencanaan yang matang, organisasi yang mempunyai kreatifitas dan inofatif dalam membuat perencanaan, organisasi yang bisa berkembang sesuai dengan tujuan dan visi misi yang sudah menjadi kesepakatan. Dewasa ini banyak sekali organisasi-organisasi yang tumbuh berkembang, namun jarang sekali diantara beberapa organisasi yang ada bisa bertahan dalam jangka waktu yang lama, mungkin karena beberapa hal yang bisa mempengaruhi sebuah organisasi itu bisa putus di tengah jalan atau mecet tidak bisa menyelesaikan program/tidak menuai hasil (gagal), ataukah karena perencanaan program itu dulunya tidak di pikirkan secara matang. Ataukah karena kurang kompak atau bagaimana ini? Bisa juga ini malah yang menjadi sebuah masalah yang harus di pecahkan.

Kerjasama yang baik bisa menjadi awal sebuah organisasi bisa berjalan dengan lancar dan baik, disamping itu juga perlu adanya komunikasi yang baik pula. Tanpa ada kerjasama dan komunikasi yang baik, sebuah organisasi tidak akan bisa bertahan lama,padahal suatu organisasi yang baik dilihat petama kali dari bisa bertahan lama "tidak cepat bubar" atau sebaliknya "konsisten. Halhal yang menunjang organisasi bisa di katakan baik atau sukses adalah :

$$
\text { Lingkungan Hidup dan Bencana }
$$


1. Kepemimpinan. Tanpa adanya pemimpinan yang punya sikap tanggap,tegas,tanggung jawab,kemampuan yang lebih,dan konsisten dengan tanggung jawab,sebuah organisasi tidak akan bisa maju dan baik.

2. Anggota atau pengurus di masing-masing program. Jika kepengurusan tidak bisa menjalankan tugas dan kewajiban dengan baik, organisasi juga tidak akan maju atau konsisten.

3. Tempat atau kantor. Sebuah organisasi yang baik juga di tunjukan dengan adanya sebuah kantor atau tempat "punya kantor.

4. Jaringan. Ini juga termasuk salah satu yang menunjang organisasi itu di katakan baik, banyaknya jaringan yang di bangun, ini semakin menunjukan organisasi itu bisa di katakan organisasi yang baik atau maju.

5. Komunikasi dalam organisasi. Jika dalam satu ruang organisasi tidak ada komunikasi yang baik, bahkan tidak ada keterbukaan dalam satu ruang yang beda pemikiran juga beda tujuan, sehingga tidak ada penyelesaian atau jalan keluar untuk memecahkan suatu masalah, organisasi itu tidak akan bisa bekerja dengan maksimal dan hasilnya juga tidak maksimal.

6. Managemen. Organisasi yang baik managemennya juga harus baik, tersusun dengan rapi dan terorganisir dengan baik.

7. Budaya dalam keorganisasian. Yang di maksud dengan budaya disini adalah kebiasaan-kebiasaan yang ada dalam organisasi,entah itu kebiasaan yang baik atau kebiasaan yang tidak baik,seperti tidak ada keseriusan dalam menjalankan tugas,mengabaikan waktu yang sudah menjadi kesepakatan "tidak tepat waktu",tidur di waktu jam kerja,dan lain-lainnya.

Jadi,di sini bisa disimpulkan bahwa organisasi yang baik adalah organisasi yang bisa konsisten dan punya hasil yang konkrit. Tanpa hasil yang konkrit, organisasi itu tidak bisa dikatakan organisasi yang baik, karena semuanya hanyalah sebuah program tanpa penyelesaian, disamping itu juga harus konsisten, organisasi yang tidak konsisten macet di tengah perjalanan berarti organisasi itu gagal menjalankan program, itu juga tidak baik.

\section{KESIMPULAN}

Pasar merupakan salah satu klaster dalam penyebaran virus Covid 19 di wilayah Surabaya Raya. Untuk itu perlu adanya kesadaran dari para pihak yang ada di pasar seperti pedagang, pembeli, pengelola pasar bahkan para pihak lainnya. Pelatihan pasar tangguh kepada para relawan ini diharapakan dapat memberikan sosialisasi dan edukasi mengenai pelaksanaan protokol kesehatan untuk setiap kegiatan di pasar.

\section{UCAPAN TERIMA KASIH}

Ucapan terima kasih kepada Universitas Wijaya Putra dan Badan Penanggulangan Bencana Daerah (BPBD) Provinsi Jawa Timur yang telah memberikan kontribusi dalam pelaksanaan kegiatan pelatihan pasar tangguh untuk penekanan penyebaran virus Covid 19 di wilayah Surabaya Raya.

\section{REFERENSI}

1. Ahmad Fathoni, Dampak Covid 19 dan Kebijakan PSBB Pemerintah Terhadap UMKM di Wiyung Surabaya, Jurnal Prodi Ekonomi Syariah, STAI Lugman Al Hakim Surabaya, 2020.

2. Hadi Sucipto, Pengaturan Pasar Tradisional, Pusat Perbelanjaan dan Toko Modern Dalam Mewujudkan Persaingan Usaha Sehat Menurut Hukum Positif di Indonesiaa, Jurnal IUS, vol V, Nusa Tenggara Barat, 2017

3. Narto, Penguatan Strategi Pemasaran Pudak di Tengah Pandemi Covid 19 Untuk Meningkatkan Keunggulan Bersaing Usaha Mikro Kecil Menengah Kota Gresik, Jurnal INTECH, vol 6, Universitas Serang, 2020, Serang.

4. Dwi Putri Robiul, Kebijakan PSBB Pemerintah Kota Surabaya Dalam Mencegah Penyebaran Virus Covid 19, SAHAFA, vol. 3, Surabaya, 2020 